$14^{\text {th }}$ Conf. Agric. Develop. Res., Fac. Agric., Ain Shams Univ.,

March, 2019, Cairo, Egypt

Special Issue, 27(1), 37 - 50, 2019

Website: http://strategy-plan.asu.edu.eg/AUJASCI/

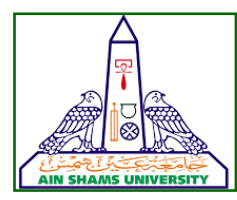

\title{
IMPACT OF DROUGHT STRESS ON SOME GROWTH, BIOCHEMICAL AND ANATOMICAL PARAMETERS OF Thymus vulgaris $L$.
}

\author{
Reham, E. Farag, Ola. H. Abdelbar and Shehata S.A. \\ Botany Dept., Fac. of Agric., Ain Shams Univ., P.O. Box 68, Hadyek Shoubra 11241, \\ Cairo, Egypt \\ *Corresponding author: said_shehata@agr.asu.edu.eg
}

Received 19 September, 2018, Accepted 2 October, 2018

\begin{abstract}
Two pot experiments were conducted on the $17^{\text {th }}$ and $19^{\text {th }}$ of march during 2015 and 2016 growth seasons respectively at the greenhouse, Dept. Agric. Botany, Faculty of Agriculture, Ain Shams University, Shoubra El-Kheima, Egypt to investigate the impact of drought stress on some growth, biochemical and anatomical parameters of Thymus vulgaris L. Plants were exposed to two different irrigation levels: $70-80 \%$ and $30-40 \%$ of water holding capacity (WHC) as well-irrigated and drought stressed plants respectively. The results indicated that all investigated growth parameters and leaf photosynthetic pigments were decreased significantly by exposing to drought stress. There were significant increase in the concentration of reactive oxygen species (ROS) as indicated by measuring of $\mathrm{H}_{2} \mathrm{O}_{2}$ and malondialdehyde (MDA). A similar trend was observed in respect to osmolytes including proline, total soluble sugars and free amino acids. Also, drought stress increased significantly total soluble phenols and the specific activity of Phenylalanine ammonia-lyase (PAL) and Polyphenol oxidase (PPO), whereas, no significant differences were detected in peroxidase (POD). The anatomical examination showed that there were several significant changes associated with water limited supply in the stem and leaf of plants.
\end{abstract}

Keywords: Thymus vulgaris, drought, pigments, ROS, osmolytes, antioxidant enzymes and anatomical parameters.

\section{INTRODUCTION}

Thyme (Thymus vulgaris L.) is considered one of the most ubiquitous cultivated plants worldwide.
It has several of aromatic and medicinal properties. The leaves could be used fresh or dried as a flavoring agent in many culinary applications. They own a high ratio of minerals $(\mathrm{K}, \mathrm{Ca}, \mathrm{Mg}, \mathrm{Fe}, \mathrm{Mn}$, and $\mathrm{Se}$ ), antioxidants (flavonoids, phenolic compounds like pigenin, naringenin, luteolin, thymonin, lutein, and zeaxanthin) and vitamins (A, B6, B9, C, $E$ and K) (Alireza et al 2015 and Dauqan \& Abdullah, 2017). Moreover, the volatile oil of common thyme (obtained by distillation of the fresh leaves and flowering tops) contains $20-54 \%$ thymol (monoterpene) which is considered the main active ingredient with numerous pharmacological properties (Fachini-Queiroz et al 2012 and Nikolić et al 2014).

Drought Stress is considered the most environmental challenges which represent a serious threat to agriculture worldwide, it cause a considerable loss in the yield and quality for many economical crops. Plants can respond to drought stress at morphological, anatomical, physiological, biochemical and molecular levels with modifications that allow the plant to avoid the stress or to increase its tolerance (Smirnoff, 1993 and Ibrahim et al 2015). These responses include substantially changes in the content of reactive oxygen species (ROS) and the activity of antioxidant systems (enzymatic and non-enzymatic) that minimize or preventing the occurrence of oxidative damage under stress conditions (Ibrahim et al 2016). Among these antioxidants, phenolic compounds and their related enzymes (PAL, PPO and POD) have received considerable attention for being potentially protective factors against drought stress (Ibrahim et al 2015). Moreover, drought stress affects leaf water status, pigments and stomatal conductance leading to inhibit photosynthesis 
(Farooq et al 2009 and Saraswathi \& Paliwal, 2011).

Increasing plant resistance to drought stress would be the most economical approach to improving agricultural productivity and reducing agricultural use of fresh water resources (Xiong et al., 2006). Therefore the purpose of the present study was to evaluate the mechanism/s of drought tolerance in thyme plants by investigation of several parameters including growth, biochemical compounds and anatomical features.

\section{MATERIALS AND METHODS}

\section{Plant materials and growth conditions}

Two pot experiments were conducted on the $17^{\text {th }}$ and $19^{\text {th }}$ of march of 2015 and 2016 respectively at the greenhouse, Dept. Agric. Botany, Faculty of Agriculture, Ain Shams University, Shoubra El-Kheima, Egypt to investigate the impacts of drought stress on some growth, biochemical and anatomical parameters of Thymus vulgaris $\mathrm{L}$. Plants were exposed to two different irrigation levels initiated after 20 days after planting (DAP). The well-irrigated plants had kept at $70-80 \%$ of water holding capacity (WHC) whereas; the drought stressed ones subjected to $30-40 \%$ of WHC. Water holding capacity of the experimental soil was determined using different calibrated tensiometer to each level of irrigation.

Uniform thyme plants (Thymus vulgaris L.) were purchased from a private garden in Qalubia governorate, Egypt; after that plants were identified at Flora and Phytotaxonomy Researches, Horticultural Research Institute, Agricultural Research Center; Egypt to know their systematic position according to Engler's system as represented by Melchior (1964). Uniform thyme plants were transplanted in $20 \mathrm{~cm} \times 35 \mathrm{~cm}$ plastic pots (one plant/pot) filled with $8 \mathrm{~kg}$ sandy- loam soil. The experimental design was Completely Randomized Block Design (CRBD) with three replicates, each one contains 7 pots.

\section{Growth parameters}

The growth parameters including root, shoot fresh weight and root/shoot fresh weight ratio were recorded at 60 days after planting (DAP).

\section{Biochemical constituents}

\section{Leaf pigments}

Leaves sample at 60 (DAP) were collected to determine plant pigments according to the method of Lichtenthaler and Buschmann (2001) with some modifications. $0.2 \mathrm{~g}$ of fresh leaves was homogenized with acetone $80 \%$ in dark at room temperature. Absorbance was measured in a UV/ VIS spectrophotometer. The concentrations were calculated using the following equations:

Chl a $(\mu \mathrm{g} / \mathrm{ml})=12.25 \mathrm{~A}_{663.2}-2.79 \mathrm{~A}_{646.8}$
Chl b $(\mu \mathrm{g} / \mathrm{ml})=21.50 \mathrm{~A}_{646.8}-5.10 \mathrm{~A}_{663.2}$

Total Chl $=\mathrm{Chl} \mathrm{a}+\mathrm{Chl} \mathrm{b}$

Carotenoids $(\mu \mathrm{g} / \mathrm{ml})=\left(1000 \mathrm{~A}_{470}-1.82 \mathrm{Chl} \mathrm{a}-\right.$ 85.02 Chl b) / 198 f.wt

After that the calculations were done as $\mathrm{mg} \cdot \mathrm{g}^{-1}$

\section{Reactive oxygen species (ROS)}

\section{a- Lipid peroxidation (MDA)}

The level of lipid peroxidation of thyme plants at 60 (DAP) under the stressed and the wellirrigated plants was measured in the leaves as malondialdehyde (MDA). Content was determined by reaction with 2-thiobarbituric acid (TBA) reactive substances as described by Giannakoula et al (2008), according to Heath and Packer (1968). Tissue was homogenized in $0.3 \%$ TBA in $10 \%$ trichloracetic acid (TCA) at $4 \circ \mathrm{C}$. The concentration of MDA was calculated from the difference of the absorbance at 532 and $600 \mathrm{~nm}$ spectrophotometrically using the extinction coefficient of $155 \mathrm{mmol}^{-1}$ $\mathrm{cm}^{-1}$ and expressed as nmol (MDA) $\mathrm{g}^{-1}$ fresh weight.

\section{b- Hydrogen peroxide $\left(\mathrm{H}_{2} \mathrm{O}_{2}\right)$ concentration}

The colorimetric determination of hydrogen peroxide concentration at $390 \mathrm{~nm}$ in leaf tissues using potassium iodide was assayed as described by Loreto and Velikova (2001). A half gram of leaves at 60 (DAP) was homogenized in $3 \mathrm{~mL}$ of $1 \%(\mathrm{w} / \mathrm{v})$ tri-chloroacetic acid (TCA). The homogenate was centrifuged at $10,000 \mathrm{rpm}$ at $4^{\circ} \mathrm{C}$ for 10 min. Subsequently, $0.75 \mathrm{~mL}$ of the supernatant was added to $0.75 \mathrm{~mL}$ of $10 \mathrm{mM} \mathrm{K}$-phosphate buffer $(\mathrm{pH} \mathrm{7.0)}$ and $1.5 \mathrm{~mL}$ of $1 \mathrm{M} \mathrm{KI}$. A Standard curve of $\mathrm{H}_{2} \mathrm{O}_{2}$ was done to calculate its concentration ( $\mu \mathrm{mol} \mathrm{g}{ }^{-1}$ f.wt) in plant tissues. 


\section{Determination of osmolytes}

\section{a- Proline}

Leaves from both irrigation treated plants at 60 (DAP) were cut into small pieces, weighed, placed separately in glass vials containing $10 \mathrm{~mL}$ of $80 \%$ $(\mathrm{v} / \mathrm{v})$ ethanol, and heated at $60 \circ \mathrm{C}$ for $30 \mathrm{~min}$. The extract was then filtered and diluted with $80 \%(\mathrm{v} / \mathrm{v})$ ethanol up to $20 \mathrm{~mL}$. The concentration of free proline ( $\mu$ mol.g ${ }^{-1}$ f.wt) was determined in this extract as described by Giannakoula et al (2008), following the acid-ninhydrin reagent method (Bates et al 1973).

\section{b- Free amino acids}

Free amino acids (mg. $\mathrm{g}^{-1} \mathrm{f}$.wt) were determined according to Hamilton and Van Slyke (1943). One $\mathrm{ml}$ of each sample extract was treated with $1 \mathrm{ml}$ of $10 \%$ pyridine and $1 \mathrm{ml}$ of $2 \%$ ninhydrine solution. The optical densities of these colored solutions were then read at $570 \mathrm{~nm}$. Glycine solution were prepared as standard.

\section{c- Total soluble sugars}

Ethanol extracts from each treatment of thyme leaves as used for proline assay, were diluted 10 times with $80 \%(\mathrm{v} / \mathrm{v})$ ethanol for the assay of soluble sugars (mg.g ${ }^{-1}$ f.wt) as described previously by Giannakoula et al (2010). Briefly, the diluted extracts were added, drop-by-drop, in $2 \mathrm{~mL}$ anthrone reagent test tubes in an ice bath and left to mix the content. Fully mixed samples were incubated in a water bath at $90 \circ \mathrm{C}$ for $15 \mathrm{~min}$ and cooled, and absorbance was read at $625 \mathrm{~nm}$ using a UV spectrophotometer.

\section{Determination of total soluble phenols}

The extraction of dry leaves in cold $\mathrm{MeOH} 85 \%$ was used to determine total soluble phenols (mg. $\mathrm{g}^{-1}$ f.wt) according to the method of Folin-Denis as described by Shahidi and Naczk (1995) by reading the developed blue color at $725 \mathrm{~nm}$ using spectrophotometer.

\section{Enzyme assays}

To prepare the extraction of enzymes and soluble proteins, fresh leaves were homogenized in 5 $\mathrm{mL}$ phosphate buffer $(0.1 \mathrm{M}, \mathrm{pH} 7.8)$, centrifuged at $10,000 \times \mathrm{g}$ for $20 \mathrm{~min}$ at $4 \circ \mathrm{C}$ and then the su- pernatant was used for assays. Soluble proteins were evaluated by the method of Bradford (1976).

\section{a- Polyphenol oxidase (PPO)}

Polyphenol oxidase (PPO) (EC 1.14.18.1) activity was measured according to Oktay et al., (1995). The reaction mixture consisted of $100 \mu \mathrm{l}$ crude enzyme, $600 \mu \mathrm{l}$ catechol and $2.3 \mathrm{ml}$ phosphate buffer $(0.1 \mathrm{M}, \mathrm{pH} 6.5)$. The absorbance at $420 \mathrm{~nm}$ was recorded at zero time and after $1 \mathrm{~min}$. One unit of PPO activity was defined as the amount of enzyme that caused an increase in absorbance of 0.001 per min at $420 \mathrm{~nm}$. The enzyme activity was expressed as unit. $\mathrm{mg}^{-1}$ protein.

\section{b- Phenylalanine ammonia-lyase (PAL)}

The activity of phenylalanine ammonia-lyase, PAL (E.C 4.3.1.5) was assayed as described by Lister et al (1996). The PAL assay reaction consisted of $100 \mu \mathrm{L}$ crude extract and $900 \mu \mathrm{L}$ of $6 \mu \mathrm{mol}$ phenylalanine in $500 \mathrm{mM}$ tris- $\mathrm{HCl}$ buffer $(\mathrm{pH} 8.5)$. The mixture was incubated at $3{ }^{\circ} \mathrm{O}$ for $1 \mathrm{~h}$ and measured spectrophotometrically at $290 \mathrm{~nm}$. Trans- cinnamic acid was used as standard.

\section{c- Peroxidase (POD)}

The activity of peroxidase, POD (EC 1.11.1.7) was assayed according to the method of Dias and Costa (1983) with some modifications. The following reaction mixture $(3 \mathrm{ml})$ consisted of $10 \mathrm{mM}$ sodium phosphate buffer, $\mathrm{pH} 7.0,50 \mu \mathrm{L}$ enzyme extract and guaiacol 1\% (v:v) aqueous solution. The reaction was started by adding $\mathrm{H}_{2} \mathrm{O}_{2}$ at 100 $\mathrm{mM}$. The changes of optical density at $470 \mathrm{~nm}$ were recorded in a spectrophotometer. Unit of enzyme (IU) equal $0.01 \Delta \mathrm{OD}$. $\mathrm{min}^{-1}$. The specific activity expressed as (IU. $\mathrm{min}^{-1} \cdot \mathrm{mg}^{-1}$ protein).

\section{Anatomical study}

Specimens of the unstressed and stressed plants (leaves and stems) were collected. Plant samples were fixed in FAA (formalin, acetic acid and $70 \%$ ethyl alcohol, 5:5:90/100 ml) for $24 \mathrm{~h}$ at room temperature. Then it dehydrated and processed using the schedule of the paraffin method according to Johansen (1940). Transverse sections $(12 \mu \mathrm{m})$ in thickness were made by LEICA rotary microtome model RM 2125 RTS and fixed on slides by means of Haupt's adhesive Sass (1951). Double stained with Safranin-Fast green combination were made and then mounted in Canada balsam Sass (1951). Anatomical exami- 
nation and measurements were achieved using a LEICA light research microscope model DM-2500 supplied with a digital camera

\section{Statistical analysis}

Data of the two seasons were arranged and statistically analyzed using SAS Institute Inc. (1988) software. The comparisons among means of the different treatments were determined as illustrated by Snedecor and Cochran (1982). Standard division of the means (SD) was calculated and Duncan's test based on a probability of $P \leq$ 0.05 was used to determine significant differences between means.

\section{RESULTS AND DISCUSSION}

\section{Changes in the growth parameters}

As shown in Figure (1) water deficit caused significant $(P \leq 0.05)$ decreases in all studied growth parameters of the thyme plants including shoot fresh weight, root fresh weight and root/shoot fresh weight ratio compared to the well-irrigated ones in both seasons. These results were confirmed in many species that belong to family Lamiaceae including Thymus vulgaris (Aziz et al 2008); Majorana hortensis Moench (Massoud et al 2010); Ocimum Sp. (Dos Santos et al 2016) and Satureja hortensis (Miranshahi and Sayyari, 2016).

Drought stress is considered one of the most limiting factors for plant growth and development because it affects cell turgor, enzyme activities and energy supply which required for different phases of plant growth and development including cell division, elongation and differentiation (Taiz and Zeiger 2002).

Furthermore, drought stress can trigger multiple of molecular, biochemical and physiological responses that affect negatively plant growth and development; among these effects: (1) increasing the level of reactive oxygen species (ROS) in plant tissues leading to a series of oxidative damage for most plant cell components like proteins, lipids and nucleic acids (Impa et al 2012 and Noctor et al 2014), (2) inhibiting the photosynthesis through impairing the electron transport systems inside the chloroplast and destroying its pigments. Moreover, reducing water supply limits the entry of $\mathrm{CO}_{2}$ and the rate of its carboxylation reaction by inducing the partial stomatal closure and affecting the effi- ciency of RuBisCO (Smirnoff, 1993), (3) changing the level of endogenous phytohormones such as $A B A$, ethylene, $G_{3}$, cytokinins and auxins and altering their complex relationships with each other and consequently their dynamic and complementary actions which related to plant growth and development (Taiz and Zeiger 2002; Bielach et al., 2017).

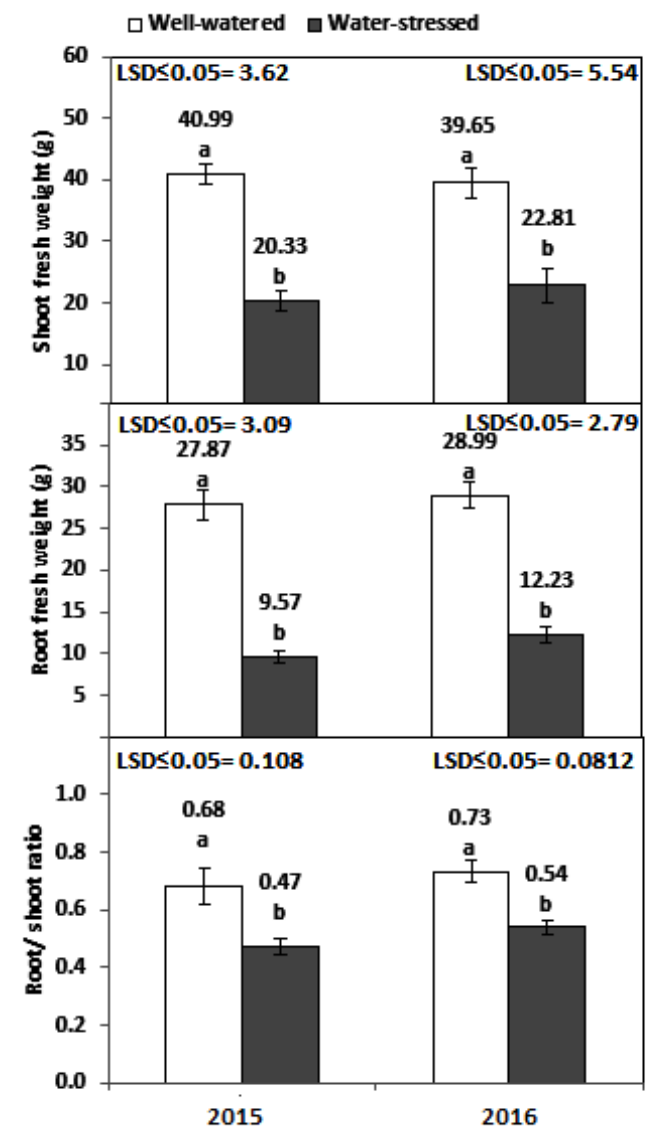

Fig. 1. Effect of drought stress on some growth parameters of thyme plants during the seasons of 2015 and 2016.

\section{Changes in the leaf pigments}

Data in Figure (2) illustrate that water stressed plants reduced significantly $(P \leq 0.05)$ the concentration of chlorophyll $\mathrm{a}, \mathrm{b}$ and total chlorophyll in both seasons compared to the well-irrigated plants in both seasons.

This reduction might be attributed to increase the production of reactive oxygen species (ROS), 

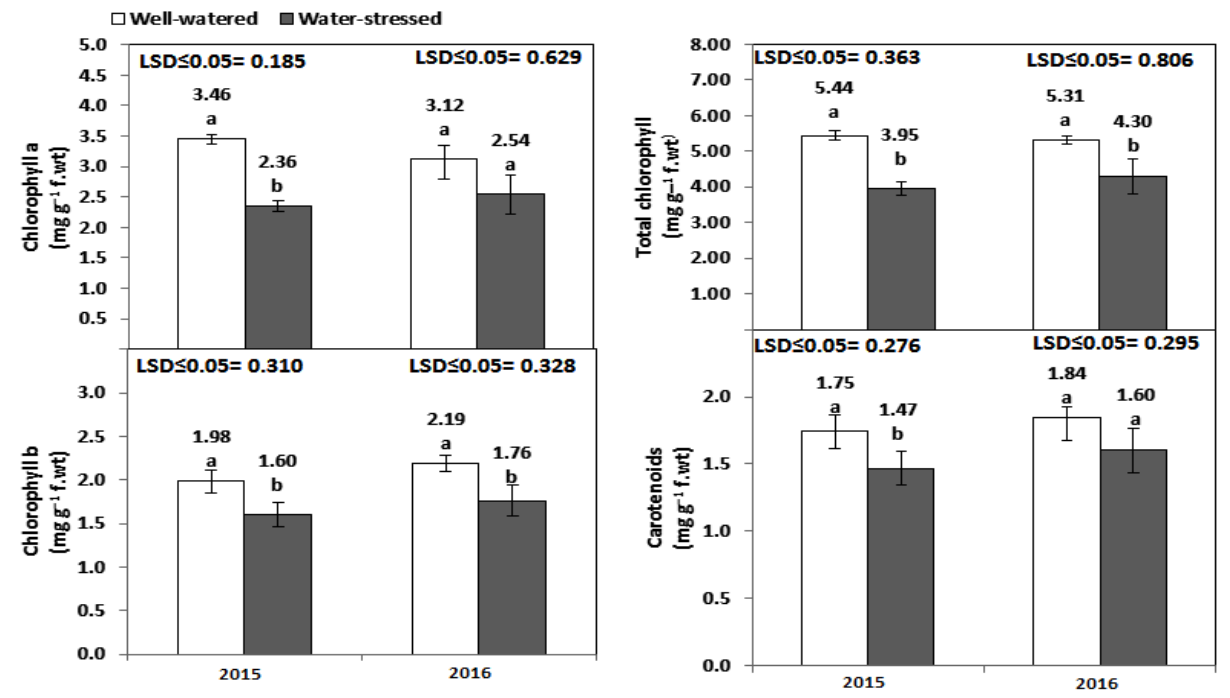

Fig. 2. Effect of drought stress on leaf pigments of thyme plants during the seasons of 2015 and 2016 .

which in turn displayed oxidative stress of chloroplast membranes during water deficit. These results were in agreement with Smirnoff (1993). Another explanation could be suggested in this respect; this reduction may be considered as an important regulatory step to avoid the exceeding light absorbance and to restrict the over reduction of photosynthetic electron transport chain and consequently the generation of ROS. (Mazars et al 2010).

As well as thyme plants under water stress showed an obvious reduction in the concentration of carotenoids compared to the unstressed ones in both seasons. This effect reached the level of significance in the first season compared to the control. This response could be occurred through highly uses of carotenoids to build up more ABA particularly under water stress, which it is considered the major signal to drought stress (Taiz and Zeiger, 2002) .

\section{Changes in the Hydrogen peroxide $\left(\mathrm{H}_{2} \mathrm{O}_{2}\right)$ and lipid peroxidation}

Reactive oxygen species (ROS) haves been reported as being products of both biotic and abiotic stresses (Reddy et al 2004). These molecules are responsible for most the oxidative damages in the biological structures including DNA, RNA, amino acids, protein and lipid (Johnson et al 2003). Therefore plants under stresses possess efficient antioxidant systems that minimize or preventing the occurrence of oxidative damage.

Data presented in Figure (3) show that there were significant increases in the concentration of $\mathrm{H}_{2} \mathrm{O}_{2}$ and the level of Lipid peroxidation as indicated by increasing the concentration of malondialdehyde (MDA) in leaf tissues of the drought-stressed plants compared to the well-irrigated ones in both seasons.

Hydrogen peroxide $\left(\mathrm{H}_{2} \mathrm{O}_{2}\right)$ is one of the most stable ROS which produced in plant cell during different physiological processes including photosynthesis, photorespiration and relatively to a lesser extent in respiration; it plays an important role as a signaling molecule under stressful conditions (Ślesak et al 2007). This response could help plants to develop their defense mechanisms against various stressful factors either biotic or abiotic ones. It can induce defense genes which required in the induction of systemic acquired resistance (Kuzniak and Urbanek, 2000).

Malondialdehyde (MDA) is also widely known as a biochemical marker to increase the activity of ROS and the oxidative stress in plant tissues under adverse conditions. It is considered the most final product of lipid peroxidation and an important indicator to the oxidative damage which could be occurred to the cellular membranes under different stresses conditions (Angel Catala, 2012). In this study, the increases in the concentration of MDA in the drought-stressed plants could be attributed to increase ROS especially $\mathrm{H}_{2} \mathrm{O}_{2}$. 


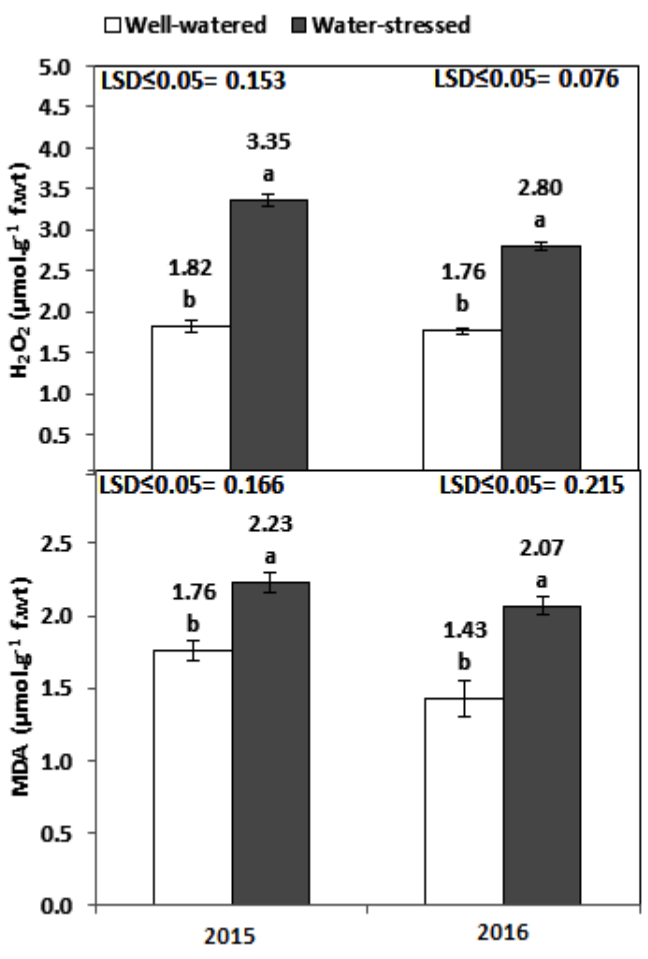

Fig. 3. Effect of drought stress on the concentration of $\mathrm{H}_{2} \mathrm{O}_{2}$ and malondialdehyde (MDA) of thyme plants during the seasons of 2015 and 2016.

\section{Changes in the osmolytes}

Data in Figure (4) show that plants under drought stress revealed a considerable and significant $(P \leq 0.05)$ increases in the soluble sugars, proline and free amino acids concentration compared to those of the well-irrigated ones in the two seasons.

Generally, it is well established that accumulation all of these organic substances which are known totally osmolytes or compatible solutes is very an essential and a common key response for plants to counteract the adverse effects of water deficit (Oraki et al 2012 and Ibrahim, 2014). They can adjust the osmotic potential leading to increase the absorption of water and improve tolerance capacity of plants to drought stress (Misra \& Gupta 2005 and Naz et al 2016). Moreover, it can protect the vital enzymes and the other different plant cell components from the fatal oxidation by scavenging ROS (Farooq et al 2012)

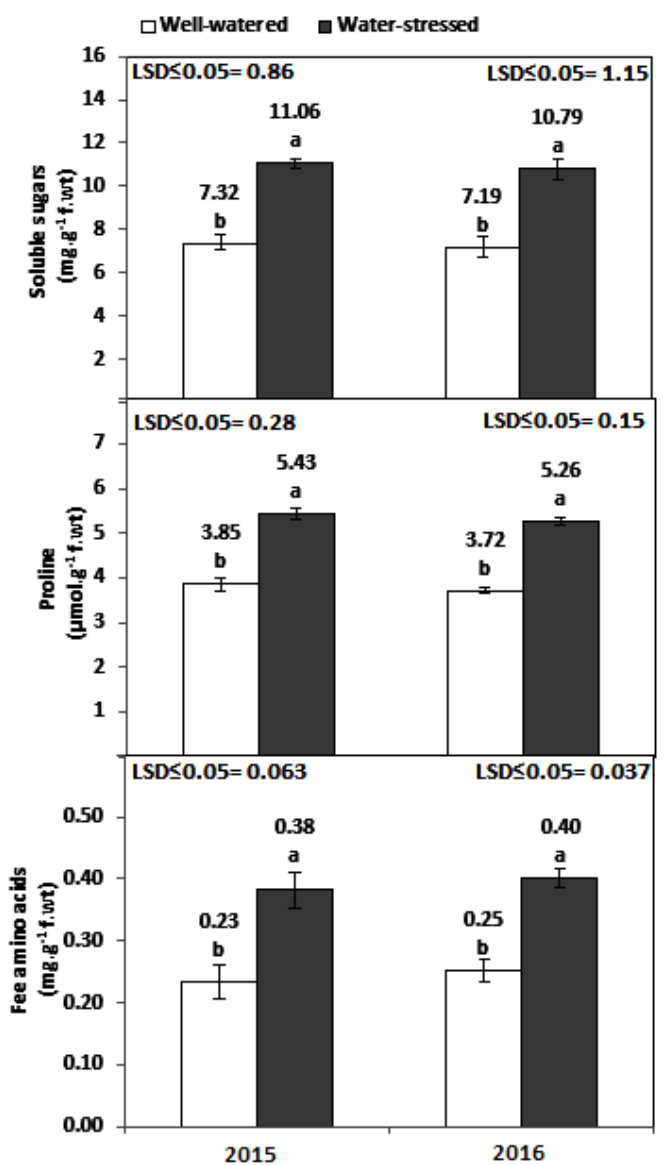

Fig. 4. Effect of drought stress on the concentration of total soluble sugars, proline and free amino acids of thyme plants during the seasons of 2015 and 2016.

\section{Changes in the Phenolic compounds and their related enzymes}

Data presented in Figure (5) show that total soluble phenols revealed a significant increase in the water- stressed plants compared to the wellirrigated ones in both seasons. A similar trend was observed in the specific activity of phenylalanine ammonia-lyase (PAL) in the first season whereas, in the second season, these increases did not reach the level of significance.

The increases in the total soluble phenols could improve the antioxidant capacity, scavenging systems for ROS which act as a carbon sink in plants under water stress (Weidner et al 2009) The substantial progress in the PAL activity of the stressed plants is considered an important regulatory step in the formation of many phenolic compounds and secondary metabolites in plants which play many 


\section{of Thymus vulgaris $\mathrm{L}$.}

considerable roles under stress conditions. This reaction occurs via the elimination of an ammonia molecule from phenylalanine to form cinnamic acid (Taiz, and Zeiger, 2002).

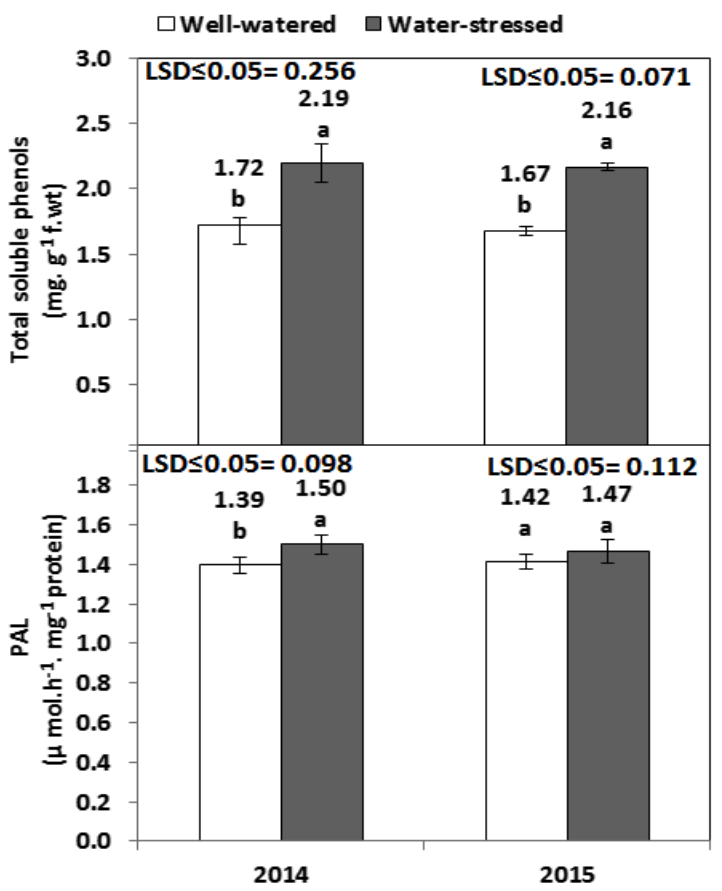

Fig. 5. Effect of drought stress on the concentration of total soluble phenols and the specific activity of phenylalanine ammonia-lyase (PAL) of thyme plants during the seasons of 2015 and 2016

Moreover, data presented in Figure (6) indicate that the specific activity of polyphenol oxidase (PPO) in the leaf tissue of Thymus vulgaris $L$ was increased significantly by exposing to drought stress compared to the well-irrigated plants in both season. PPOs are ubiquitous group of enzymes in angiosperms, they are inducible by both biotic and abiotic stresses, and have been implicated in several physiological processes including plant defense against different stresses. They are involved in the mehler reaction, photoreduction of molecular oxygen by PSI, regulation of plastidic oxygen levels and deriving of the phenylpropanoid pathway (Thipyapong et al 2007). Also, in this study, increasing the specific activity of PPO under drought stress may be related to the considerable synthesis of total soluble phenols (Figure, 5), many others phenolic compounds and secondary metabolites which are considered the substrate for PPO.

Although, it is well documented that peroxidase (POD) has been implicated in several metabolic processes related to induce resistance to various stress conditions by including lignin synthesis, phenol oxidation (Sancho et al 1996), increasing cross-linking proteins (Perez et al 2006) and another plant cell wall cross-linking reactions (Ralph et al 2004); but In this study, no significant differences were detected in the specific activity of peroxidase (POD) between the both investigated levels of irrigation in both seasons. This effect might indicate that Thymus vulgaris $\mathrm{L}$ as an aromatic plant may only depends on PAL and PPO in its secondary metabolites pathways more than POD.

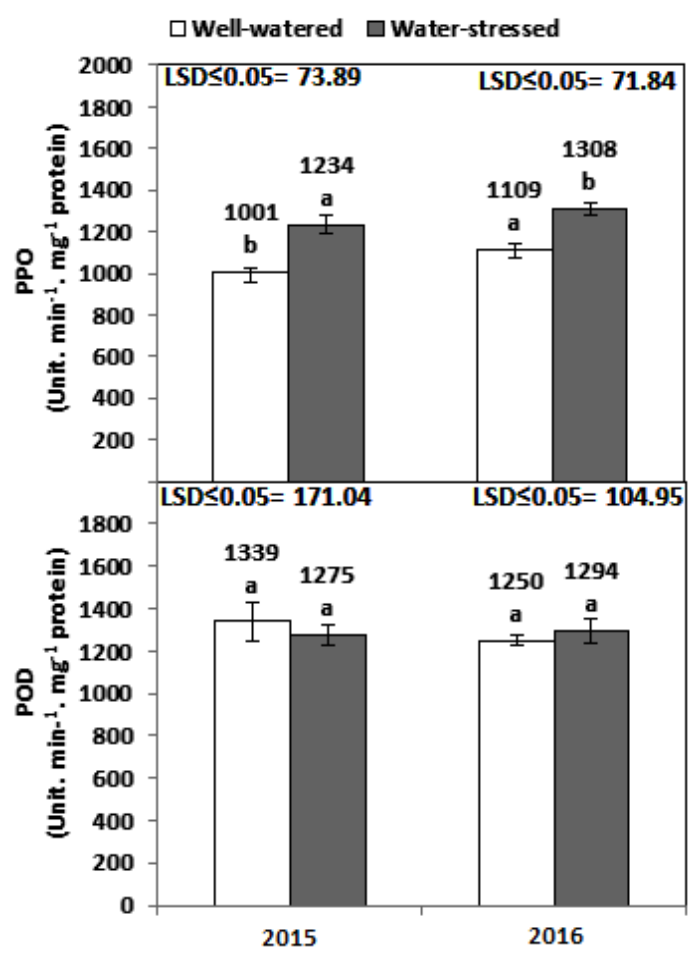

Fig. 6. Effect of drought stress on the specific activity of polyphenol oxidase (PPO) and peroxidase (POD) of thyme plants during the seasons of 2015 and 2016Changes of anatomical characteristics

As shown in Table (1) and Plate (1), it can be observed that all investigated anatomical characteristics of the leaf of thyme plants except \% palisade tissue area and the cuticle thickness were decreased significantly by exposing to drought stress. These decreases reached $75.8 \%$ in the cross section area, $80.7 \%$ in the mid vein vascular bundle area, $72.5 \%$ in the average of xylem diameter and $45.8 \%$ in the number of xylem vessels compared to the well-irrigated plants. 

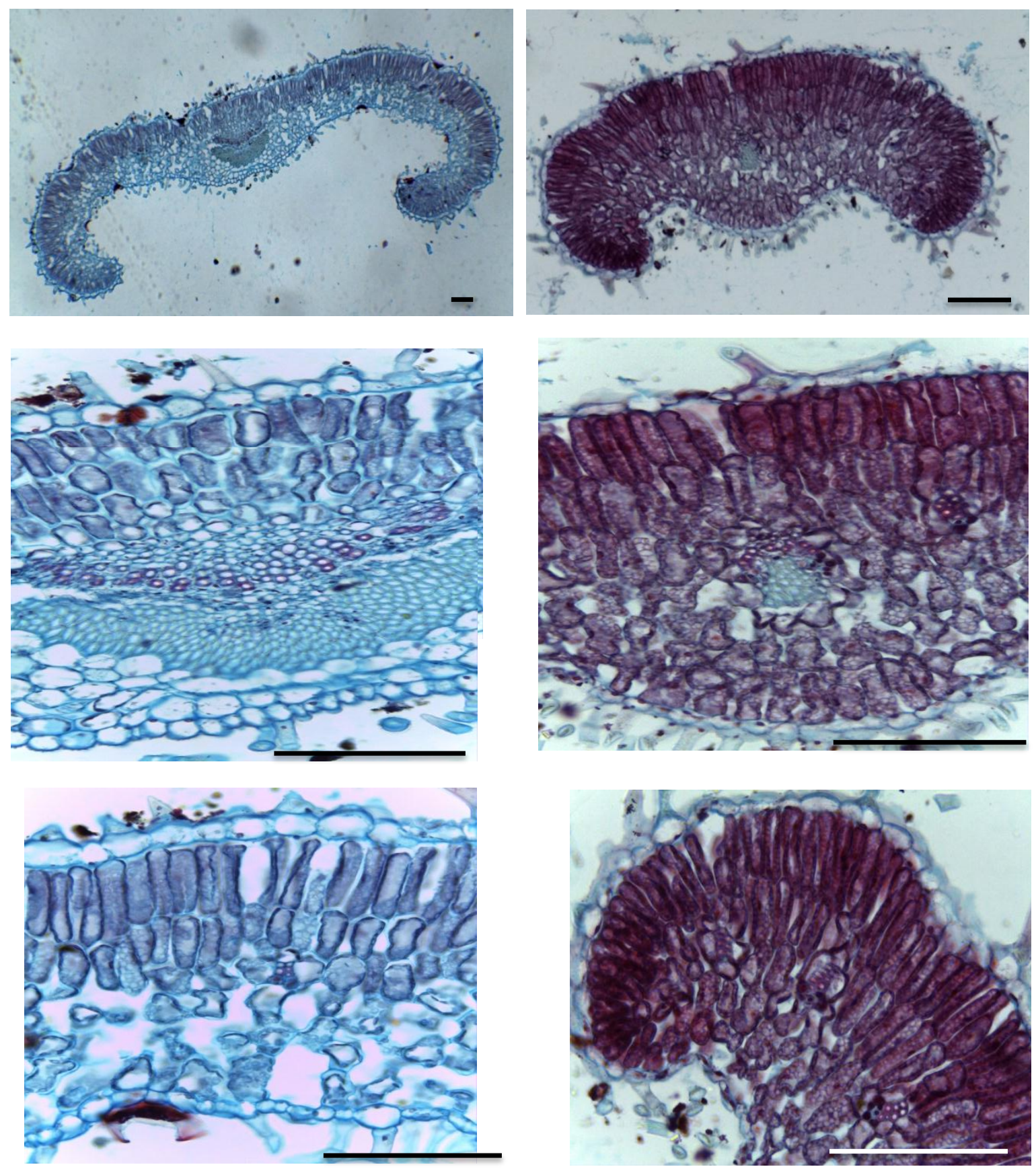

Plate 1. Transverse sections of thyme leaf plants illustrating the anatomical changes resulting from water stress: $(A, B)$ cross-section area , (C,D) midvien vascular bundle, $(E, F)$ palisade tissue. (Well-watered plants on the left and water-stressed plants on the right respectively). (Bar=100 $\mu \mathrm{m})$. 

of Thymus vulgaris $\mathrm{L}$.

Table 1. Effect of drought stress on some anatomical features of leaf of thyme plants at 60 DAP.

\begin{tabular}{|l|c|c|c|}
\hline \multicolumn{1}{|c|}{ Variable } & Well-watered & water-stressed & LSD $\leq 0.05$ \\
\hline Cross section area $\left(\mathrm{mm}^{2}\right)$ & $0.653 \pm 0.019 \mathrm{a}$ & $0.158 \pm 0.029 \mathrm{~b}$ & 0.0562 \\
Mid vein vascular bundle area $\left(\mu \mathrm{m}^{2}\right)$ & $8467 \pm 343 \mathrm{a}$ & $1637 \pm 87 \mathrm{~b}$ & 568 \\
$\%$ palisade tissue area $\left(\mu \mathrm{m}^{2}\right)$ & $50.25 \pm 3.92 \mathrm{~b}$ & $63.08 \pm 1.33 \mathrm{a}$ & 6.64 \\
Average of xylem diameter $(\mu \mathrm{m})$ & $4.29 \pm 0.27 \mathrm{a}$ & $1.18 \pm 0.09 \mathrm{~b}$ & 0.449 \\
Number of Xylem vessels & $29.5 \pm 0.5 \mathrm{a}$ & $16.0 \pm 1.0 \mathrm{~b}$ & 1.79 \\
Cuticle thickness $(\mu \mathrm{m})$ & $0.79 \pm 0.01 \mathrm{~b}$ & $1.70 \pm 0.12 \mathrm{a}$ & 0.193 \\
\hline
\end{tabular}

Means followed by different letters are significantly different at $P \leq 0.05$ according to LSD's multiple range test

Respecting the effect of drought stress on the anatomical characteristics of the stem of Thymus vulgaris (Table 2 and Plate 2), it can be observed that drought stress caused significant decrease in all studied parameters including cross section area $(30.2 \%)$, vascular bundle area $(36.7 \%)$, xylem area $(27.6 \%)$ and average of xylem diameter (40.6\%) compared to the well-irrigated plants.

Table 2. Effect of drought stress on some anatomical features of stem of thyme plants at 60 DAP.

\begin{tabular}{|c|c|c|c|}
\hline Variable & Well-watered & water-stressed & $\begin{array}{c}\text { LSD } \leq \\
0.05\end{array}$ \\
\hline $\begin{array}{c}\text { Cross section area } \\
\left(\mathrm{mm}^{2}\right)\end{array}$ & $0.652 \pm 0.009 \mathrm{a}$ & $0.455 \pm 0.01 \mathrm{~b}$ & 0.0213 \\
$\begin{array}{c}\text { Vascular bundle area } \\
\left(\mathrm{mm}^{2}\right)\end{array}$ & $0.308 \pm 0.002 \mathrm{a}$ & $0.195 \pm 0.003 \mathrm{~b}$ & 0.0564 \\
$\begin{array}{c}\text { Xylem area }\left(\mathrm{mm}^{2}\right) \\
\text { Average of } \mathrm{xylem} \\
\text { diameter }(\mu \mathrm{m})\end{array}$ & $0.217 \pm 0.005 \mathrm{a}$ & $0.157 \pm 0.007 \mathrm{~b}$ & 0.0138 \\
\hline
\end{tabular}

Means followed by different letters are significantly different at $P$ $\leq 0.05$ according to LSD's multiple range test

Generally, plants have three different strategies to respond to the abiotic stresses at the anatomical level: (1) inhibition of cell elongation, (2) localized stimulation of cell division and (3) alterations in cell differentiation status (Patakas, 2011).

Based on the above mentioned results, it could be claimed that drought stress affects negatively plant growth and alters many of biochemical components including leaf pigments, ROS, osmolytes, phenolic compounds and some of phenolic related enzymes. These effects could explain the changes that occurred in the leaf tissues at the anatomical level, For instance, enhancing the production of ROS as indicated by increasing the concentration of MDA and $\mathrm{H}_{2} \mathrm{O}_{2}$ (Figure,3) could serve as signal- ing molecules and may contribute in controlling some of developmental processes (Gapper and Dolan 2006). In particular, ROS is reported to influence cell development (e.g., xylem vessel formation; (Ros-Barcelo et al 2002), cell division (i.e., temporarily inhibiting cell cycle activity; Reichheld et al 1999), cell elongation (Schopfer, 2001).

Another possibility could be suggested to explain the effect of drought stress on plants at the anatomical level, several previous studies on many plant species have reported that drought stress causes diverse and complex changes in the hormonal homeostasis between plant growth promoters (IAA, GA3 and CKs) and inhibitors (ABA, ethylene) in the stressed plants. These responses are tightly linked to altering cell elongation, cell division, and reorientation of growth (Schrader et al 2003)

In addition, the cortex of stem consists of 5-7 thin-walled parenchyma cell layers with small intercellular spaces. The innermost cortex (endodermis) consists of thin-walled compacted of parenchyma without any specialized feature of casparian bands. Drought causes a well-developed endodermis with noticeable casparian bands on the radial walls. It is known that the casparian bands increase underdrought conditions and may help in avoid the desiccation of steller tissue (plate 2 Fig. C, D).

The above mentioned data showed the stressed plants, have an increasing into phenolic compounds which considered as intermediate compounds in the biosynthesis of lignin. This result reflected in the stem internal structure. Through increasing lignification of stellar cells consequently prevent the stem from the collapsing and reducing the risk of mechanical damage during water deficit.

Drought stress causes significant decrease in the average of inner diameter of xylem vessels in stems and leaves. 


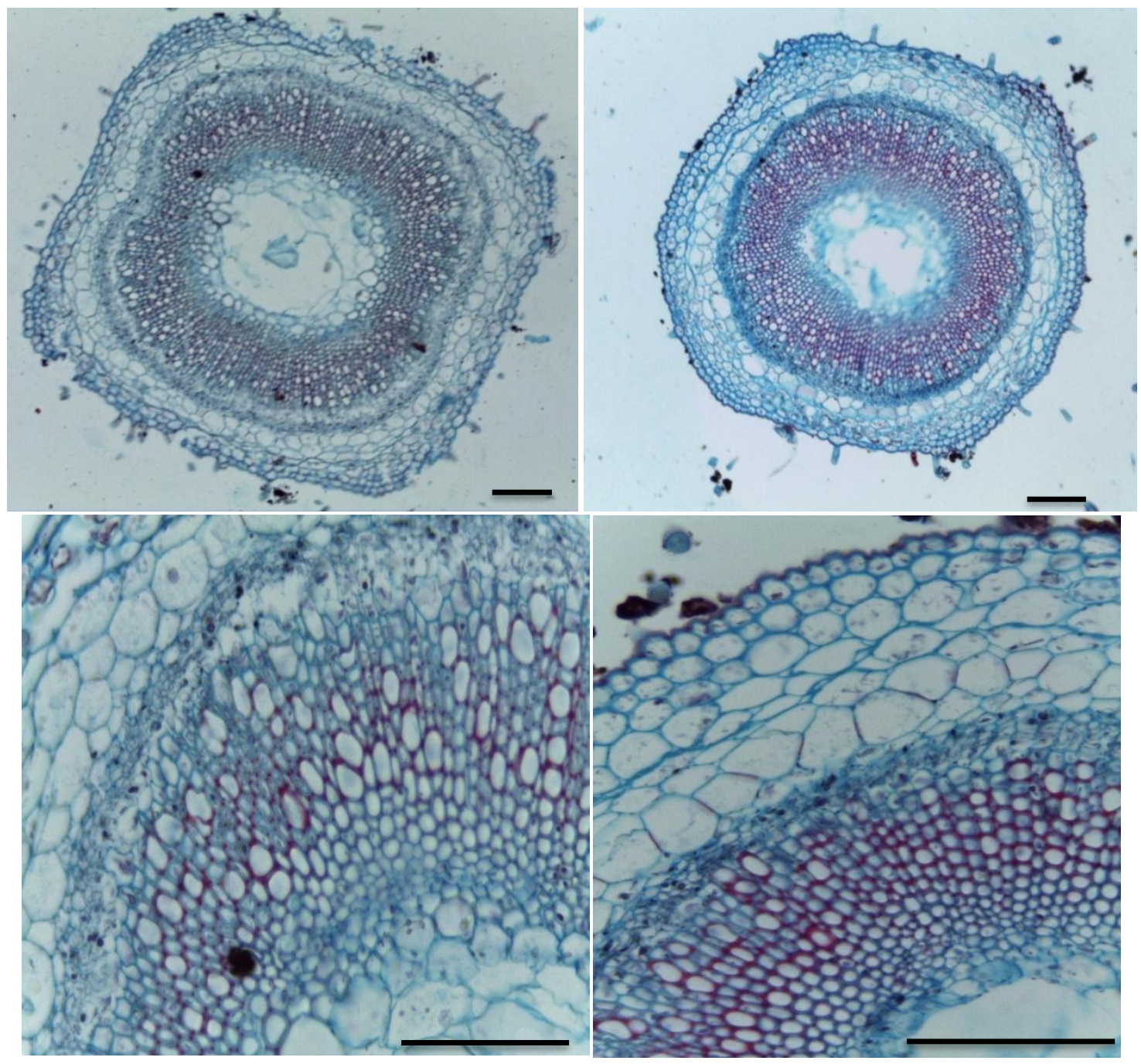

Plate 2. Transverse sections in the thyme stem plant showing the anatomical changes resulting from water stress: $(A, B)$ cross-section area and $(C, D)$ reveals the xylem area and average of xylem diameter (Well-watered plants on the left and water-stressed plants on the right respectively). (Bar $=100 \mu \mathrm{m})$.

This result may be benefit under drought condition because the narrow vessels allow slow water flow since they guarantee water transport also when larger vessels are embolised (Abdelbar, 2015).

Our result indicated that the phloem and xylem tissue areas were decreased under water stress conditions. Similar results were reported by in many previous studies (Kuutlu et al 2004 and Abdelbar \& Abd.El-Maboud 2013). These differences may be conceived as an adaptation to stress and related to loss of water.

In addition, in this study, the significant increase in $\%$ palisade tissue area under drought stress may help plants to adapt to inadequate water supply and keep suitable rate of photosynthesis because the thicker palisade parenchyma could contain larger numbers of $\mathrm{CO}_{2}$-fixation sites (Ennajeh et al 2010).

Cuticle is thought to play a critical role in plant drought tolerance through its ability to restrict transpiration or postpone the onset of cellular dehydration stress during drought (Samuels et al 2008). In this investigation, the increasing in the cuticle thickness of the leaf epidermal cells under drought stress could be attributed to induction more of cuticle lipids which was associated with reduced cuti- 
cle permeability and may be important for plant acclimation to subsequent water-limited conditions (Kosma et al., 2009).

\section{Conclusion}

According to the results of this study, it can be concluded that thyme plants (Thymus vulgaris L.) responded to drought stress by altering several of growth, biochemical and anatomical parameters which totally can help plant to tolerate and survive under water deficit condition.

\section{REFERENCES}

Abdelbar, O.H. 2015. Development of the successive cambia in Sesuvium verrucosum Raf (Aizoaceae). Annals of Agricultural Sciences. 60(2), 203-208.

Abdelbar, O.H. and Abd El-Maboud M.M., 2013 Anatomical and physiological responses of three species of Suaeda Forssk. ex Scop. under different habitat conditions Journal of Applied Sciences Research, 9 (8), 5370-5379.

Alireza, K., Faeghe H., Siamak S. and Negar B. 2015. Study of the effect of extract of Thymus vulgaris on anxiety in male rats. Journal of Traditional and Complementary Medicine, pp. 1-5.

Angel, Catala, 2012. Lipid peroxidation. Published by InTech Janeza Trdine 9, 51000 Rijeka, Croatia. First published, Printed in Croatia. www.intechopen.com

Aziz, E.E. Hendawi, Ezz El Din S.F. and Omer E.A., 2008. Effect of soil type and irrigation intervals on plant growth, essential oil yield and constituents of Thymus vulgaris plant. American-Eurasian J. Agric \& Environ. Sci. 4(4), 443-450.

Bates, L., Waldren R.P. and Teare I.D. 1973. Rapid determination of free proline for waterstress studies. Plant and Soil, 39, 205-207.

Bielach, A., Hrtyan M. and Tognetti V.B. 2017. Plants under Stress: Involvement of Auxin and Cytokinin. Int. Int. J. Mol. Sci., 18(1427), 1-29.

Bradford, M.M., 1976. A rapid and sensitive method for the quantitation of microgram quantities of protein utilizing the principle of protein-dye binding. Analytical Biochemistry, 72, 248254.

Dauqan, E.M.A. and Abdullah A., 2017. Medicinal and functional values of thyme (Thymus vulgaris L.). Herb Journal of Applied Biology \& Biotechnology. 5 (02), 17-22.
Dias, M.A. and Costa M.M. 1983. Effect of low salt concentrations on nitrate reductase and peroxidase of sugar beet leaves. J. Exp. Bot. (34), 537-543.

DosSantos, M.S., Souza L.D.S., Costa C.A.S., Gomes F.P., L.C.D.B. Costa, Oliveira R.A.D. and Silva D.D.C., 2016. Effects of water deficit on morphophysiology, productivity and chemical composition of Ocimum africanum Lour (Lamiaceae). African Journal of Agricultural Research, 11(21), 1924-1934.

Ennajeh, M., Vadel A.M., Cochard H. and Khemira H. 2010. Comparative impacts of water stress on the leaf anatomy of a droughtresistant and a drought-sensitive olive cultivar Journal of Horticultural Science \& Biotechnology 85 (4) 289-294.

Fachini-Queiroz, F.C., Kummer R., EstevãoSilva C.F., 2012. Effects of thymol and carvacrol, constituents of Thymus vulgaris L. essential oil, on the inflammatory response. Evid.-Based Complement Alt. Med., pp, 110.

Farooq, M., Hussain M., Wahid A. and Siddique K.H.M., 2012. Drought stress in plants: an overview. In: Aroca, R. (Ed.), Plant Responses to Drought Stress. Springer, Berlin Heidelberg, pp. 1-33.

Gapper, C. and Dolan L., 2006. Control of plant development by reactive oxygen species. Plant Physiol 141, 341-345.

Giannakoula, A., M. Moustakas, Syros T. and Yupsanis T., 2010. Aluminum stress induces up-regulation of an efficient antioxidant system in the Al-tolerant maize line but not in the Alsensitive line. Environ. Exp. Bot. 67, 487-494.

Giannakoula, A., Moustakasa M., Mylonab, P., Papadakisc I. and Yupsanis T., 2008. Aluminum tolerance in maize is correlated with increased levels of mineral nutrients, carbohydrates and proline, and decreased levels of lipid peroxidation and Al accumulation. Journal of Plant Physiology, 165, 385-396.

Hamilton, P.B. and Van Slyke D.D., 1943. Amino acids determination with ninhydrin. J. Biol. Chem., 150, 231-233.

Heath, R.L. and Packer L., 1968. Photoperoxidation in isolated chloroplasts. 1. Kinetics and stoichiometry of fatty acids peroxidation. Arch. Biochem. Biophys., 125(1), 189-198.

Ibrahim, M.F.M., 2014. Induced Drought Resistance in Common Bean (Phaseolus vulgaris L.) by Exogenous Application with Active Yeast 
Suspension. Middle East Journal of Applied Sciences, 4(4), 806-815.

Ibrahim, M.F.M., Bondok A.M.; Al-Senosy N.K. and Younis R.A.A., 2015. Stimulation Some of Defense Mechanisms in Tomato Plants under Water Deficit and Tobacco mosaic virus (TMV) World Journal of Agricultural Sciences 11 (5), 289-302.

Ibrahim, M.F.M., Faisal A. and Shehata S.A., 2016. Calcium Chloride Alleviates Water Stress in Sunflower Plants Through Modifying Some Physio-Biochemical Parameters American Eurasian J. Agric. \& Environ. Sci., 16 (4), 677-693.

Impa, S.M., Nadaradjan S. and Jagadish S.V.K., 2012. Drought Stress Induced Reactive Oxygen Species and Anti-oxidants in Plants. In: Ahmad, P. and M.N.V. Prasad (eds.), Abiotic Stress Responses in Plants: Metabolism, Productivityand Sustainability. Springer Science + Business Media, LLC . pp.131-147.

Jain, M.; G. Mathur; S. Koul and N. B. Sarin (2001). Ameliorative eff ects of proline on salt stress-induced lipid peroxidation in cell lines of groundnut (Arachis hypogea L.). Plant Cell Reports, 20, 463-468.

Johansen, D.A., 1940. Plant microtechnique. McGraw Hill Book Co, New York, USA, pp. 126-156.

Johnson S.M; Doherty S.J. and Croy R.R.D. (2003). Biphasic superoxide generation in potato tubers. A self-amplifying response to stress. Plant Physiol., 13, 1440-1449.

Kosma, D.K., Bourdenx, B., Bernard, A., Parsons, E.P., S. Lu, J. Joube and Jenks M.A. 2009. The Impact of Water Deficiency on Leaf Cuticle Lipids of Arabidopsis. Plant physiology, 151, 1918-1929.

Kutlu, N., Terzi R., Tekeli C., Senel G., Battal P. and Kadioglu A. 2009. Changes in anatomical structure and levels of endogenous phytohormones during leaf rolling in Ctenanthe setosa. Turk J. Biol., 33, 115-122.

Kuzniak, E. and Urbanek H., 2000. The involvement of hydrogen peroxide in plant responses to stresses. Acta Physiologiae Plantarum, 22(2), 195-203.

Lichtenthaler, H.K. and Buschmann C., 2001. Chlorophylls and carotenoids: measurement and characterization by UV-VIS spectroscopy. Current protocols in food analytical chemistry .Wiley, New York, USA, F4.3.1-F4.3.8 pp. 129.
Lister, C.E., Lancaster J.E. and Walker J.R.L., 1996. Phenylalanine ammonia-lyase activity and its relationship to anthocyanin and flavonoid levels in New Zealand grown apple cultivars. J. Am. Soc. Hort. Sci. 121(2), 281-285.

Loreto, F. and Velikova, V. 2001. Isoprene produced by leaves protects the photosynthetic apparatus against ozone damage, quenches ozone products and reduces lipid peroxidation of cellular membranes. Plant Physiol., 127, 1781-1787.

Massoud, Hekmat Y., Abdalah M.Y.A., Mosa A.A.A. and Nour Eldeen E.A.E., 2010. Effect of water stress and folair spray of humic acid on growth and essential oil quality of marjoram (Majorana hortensis Moench) plant. J. Plant Production, Mansoura University, 1(8), 1113-1123

Mazars, C., Thuleau P., Lamotte O. and Bourque S., 2010. Cross-talk between ROS and calcium in regulation of nuclear activities. Mol. Plant 3, 706-718.

Melchior, R., 1964. Tubiflorae. In Melchior, H. "Eaglers Syllabus der Pflanzenfamilien, Ban 12(2), 424-471.

Miranshahi, B. and Sayyari M., 2016. Methyl Jasmonate Mitigates Drought Stress Injuries and Affects Essential Oil of Summer Savory. J. Agr. Sci. Tech., 18, 1635-1645.

Naz, H., Akram N.A. and Ashraf M., 2016. Impact of ascorbic acid on growth and some physiological attributes of cucumber (Cucumis sativus) plants under water-deficit conditions. Pak. J. Bot. 48, 877-883.

Nikolić, M., Glamočlija J., Ferreira I.C., Calhelha R.C., Fernandes Â. and Marković T., 2014. Chemical composition, antimicrobial, antioxidant and antitumor activity of Thymus serpyllum L., Thymus algeriensis Boiss. and Reut and Thymus vulgaris L. essential oils. Industrial Crops and Products., 52, 183-190.

Noctor, G., Mhamdi A. and Foyer C.H., 2014. The Roles of Reactive Oxygen Metabolism in Drought: Not So Cut and Dried. Plant Physiology, 164, 1636-1648.

Oktay, M., Küfrevioğlu I., Kocacalıskan I. and Sakiroğlu H., 1995. Polyphenol oxidase from Amasya Apple. J. Food Sci., 60(3), 495-499.

Oraki, H., Khanjani F.P. and Aghaalikhna M., 2012. Effect of water deficit stress on proline contents, soluble sugars, chlorophyll and grain yield of sunflower (Helianthus annuus L.) hybrids. Afr. J. Biotechnol. 11, 164-168. 
Patakas, A., 2011. Abiotic Stress-Induced Morphological and Anatomical Changes in Plants. In: Abiotic Stress Responses in Plants Metabolism, Productivity and Sustainability Springer New York Dordrecht Heidelberg London, UK, pp. 21-40.

Perez, A., lez-Verdejo C.I.G., Lozano M.D., Dita M.I.A., Cubero, J.I., lez-Melendi P.G., Risueno M.C. and Rubiales D., 2006. Protein crosslinking, peroxidase and b-1,3-endoglucanase involved in resistance of pea against Orobanche crenata. J. Exp. Bot. 57(6), 1461-1469.

Ralph, J., Bunzel, M., Marita J.M., Hatfield R.D., Lu F., Kim H., Schatz P.F., Grabber J. H. and Steinhar, H. 2004 . Peroxidase-dependent cross-linking reactions of $p$-hydroxycinnamates in plant cell walls. Phytochemistry Reviews 3, 79-96.

Reddy, A.R., Chaitanyaa K.V.A. and Vivekanandan, M. 2004. Drought-induced responses of photosynthesis and antioxidant metabolism in higher plants. J. Plant Phys. 161, 1189-1202.

Reichheld, J.P., Vernoux T., Lardon F., Van Montagu M. and Inzé D. 1999. Specific checkpoints regulate plant cell cycle progression in response to oxidative stress. Plant $\mathbf{J}$. 17, 647-656

Ros-Barcelo, A., Pomar F., Lopez-Serrano M., Martinez P. and Pedreno M.A., 2002. Developmental regulation of the $\mathrm{H}_{2} \mathrm{O}_{2}$-producing system and of a basic peroxidase isoenzyme in the Zinnia elegans lignifying xylem. Plant Physiol Biochem, 40, 325-332.

Samuels, A.L., Kunst L. and Jetter, R. 2008. Sealing plant surfaces: cuticular wax formation by epidermal cells. Annu Rev. Plant Biol. 59, 683-707

Sancho, M.A., Forchetti, S.M., Pliego F., Valpuesta V. and Quesad M.A., 1996. Peroxidase activity and isoenzymes in the culture medium of $\mathrm{NaCl}$ adapted tomato suspension cells. Plant Cell Tissue Organ Cult., 44, 161167.

Saraswathi, S.G. and Paliwal K., 2011. Drought induced changes in growth, leaf gas exchange and biomass production in Albizia lebbeck and Cassia siamea seedlings. J. Environ Biol., 32, 173-178.
SAS, 1988. SAS/STAT User's Guide: Release 6.03 ed. SAS Inst. Inc., Cary, NC.

Sass, J.E., 1951. Botanical Microtechnique. 2 ed. The lowa State College Press, pp. 5-77.

Schopfer, P., 2001. Hydroxyl radical-induced cellwall loosening in vitro and in vivo: implications for the control of elongation growth. Plant $\mathbf{J}$. 28, 679-688

Schrader, J., Baba K., May S.T., Palme K.; M. Bennett; Bhalerao R.P. and Sandberg G. 2003. Polar auxin transport in the wood-forming tissues of hybrid aspen is under simultaneous control of developmental and environmental signals. Proc. Natl Acad Sci USA 100, 1009610101

Shahidi F. and Naczk M. 1995. Food Phenolics: Sources, Chemistry, Effects, Applications, Technomic Publishing Company Inc., Lancaster PA., pp. 231- 245.

Slesak, I., Marta L., Barbara K., Stanislaw K., and Zbigniew M. 2007. The role of hydrogen peroxide in regulation of plant metabolism and cellular signalling in response to environmental stresses. Acta Biochimical Polonica, 54(1), 39-50.

Smirnoff, N., 1993. The role of active oxygen in the response of plants to water deficit and desiccation. New Phytol., 125, 27-58.

Snedecor, G.W. and Cochran W.G., 1982. Statistical Methods $7^{\text {th }}$ ed. lowa State Unv., Press, lowa, U.S.A.

Taiz, L. and Zeiger E., 2002. Plant Physiology, $3^{\text {rd }}$ Ed. Sinauer Associates Inc., Sunderland, MA, USA., pp. 224, 541.

Thipyapong, P., Stout J.M. and Attajarusit J. (2007). Functional analysis of polyphenol oxidases by antisense/sense technology. Molecules, 12, 1569-1595.

Weidner, S., Karalak M., Karamac M., Kosinska A. and Amarowicz R., 2009. Phenolic compounds and properties of antioxidants in grapevine roots (Vitisvinifera L.) under drought stress followed by recovery. Acta Societatis botanicorum Poloniae 78 (2), 79-103.

Xiong, L., Wang R.G., Mao G. and Koczan J.M., 2006. Identification of drought tolerance determinants by genetic analysis of root response to drought stress and abscisic acid. Plant Physiol., 142, 1065-1074. 